\title{
Regenerative Collaboration in Higher Education: A Framework for Surpassing Sustainability and Attaining Regeneration
}

\author{
Chara Armon
}

Citation: Armon, C. Regenerative

\begin{abstract}
Many in higher education seek to define how to respond to our environmental crisis. Our 20th and early 21st century failures to resolve the crisis have revealed that a focus on "sustainability" is inadequate in its goals, methods, and public appeal. Higher education must now advance its contribution to preparing graduates to enact the regeneration the damaged natural world requires. We now must teach the deep "why" of caring for our home planet as our life partner, exceed the standard of sustainability to focus on the more enduring and restorative standard of regeneration, and offer our students knowledge and skills for effective regenerative action. Colleges and universities can define their primary goal as teaching students how to tend the flourishing and regeneration of the life community via an emphasis on regenerative collaboration. Regenerative collaboration consists of principles that can guide higher education into a stage of deep contribution to regeneration of the natural world and human well-being. The framework of regenerative collaboration promotes transformation of academic disciplines, academic departments, and courses and calls for development of practical regenerative skills to be part of every degree program. Regenerative collaboration is a means of enacting higher education's transition from a knowledge focus to a wisdom and regenerative action focus.
\end{abstract}

Keywords: sustainability education; regeneration; regenerative; collaboration; higher education; new stories; experiential education; permaculture; transformative education

\section{Introduction}

How can we transform how higher education prepares students to respond to our environmental crisis? Our failures to solve global environmental problems in the 20th and early 21st centuries have revealed that a focus on "sustainability" is inadequate in its goals, methods, and public appeal. Moreover, in the context of higher education, it is past time to abandon the simplistic approach of informing students about our environmental crisis while leaving them hopeless about its extent and with few or no skills for halting environmental damage and creating regeneration [1-4]. (Now we must teach the deep "why" of caring for our home planet as our life partner; exceed the standard of sustainability to focus on the more enduring, joyous, and restorative standard of regeneration; and offer our students knowledge and skills for effective regenerative action. Focusing on higher education, I suggest that colleges and universities define their primary goal as teaching students how to tend the flourishing and regeneration of the life community. This is a way to enact David Orr's recommendation of "a life-centered education" and Nicholas Maxwell's proposal for transitioning from a knowledge emphasis to a wisdom emphasis [58]. This calls for transformation of the purpose and focus of higher education. In this framing, higher education provides value when it promotes the conditions conducive to the flourishing and regeneration of all forms of life on Earth. I unite the ideas implied by this suggestion within the term regenerative collaboration, which consists of principles that can guide higher education into a stage of deep contribution to environmental and human regeneration. 


\section{Regenerative Collaboration}

The findings of modern science, along with the ethics and values of human cultures over time, appear to reveal regenerative collaboration as a defining feature of the natural functioning of life on Earth, at least when life is functioning successfully. Just as collaboration has come to be increasingly valued among humans, so we are finding increasing scientific evidence of collaboration in nature. Collaboration is amply present on Earth, and that simple fact requires more of our attention. We have mounting evidence for understanding life on Earth as a multi-species collaboration in a continual process of regenerative self-renewal. The collaborations with which ecosystems and inter-species relationships often function is communicated via scientific terms such as mutualism, symbiosis, and ecosystem services. Mutualistic symbiosis is being discovered among increasingly numerous species $[9,10]$. As Guimarães et al. note, "Mutualisms represent cornerstones for the most diverse ecological communities on Earth" [10]. For example, we have discovered that bacteria function in communicative communities and also collaborate with other species, such as squid [9,11]. Additionally, the very evolution of life on Earth may have originated through forms of bacteria collaborating with one another [11,12]. We also know that plants produce the oxygen breathed by animals (including humans), while animals exhale the carbon dioxide plants need. Soil microbes' collaborative relationships with plants enable plant growth, including the production of the food humans eat, and soil mycorrhizae facilitate communication and nutrient sharing among trees $[4,11,13]$. Pollinating insects and flowering plants co-exist in a mutualistic relationship, as do seed-producing plants and the animals who ingest and disperse the seeds [10]. The human digestive system functions only with the aid of numerous microbes in the gut, and the same is true for herbivorous ruminant mammals and other animals [9]). Some plants, such as sweetgrass, even thrive with human use [4], while others, such as domesticated crops, may be dependent on human cultivation. In human history, "Mutualistic interactions actually supported the success of humankind in spreading and becoming the dominant species across the planet. Our key mutualistic partners were species that are now very abundant and cosmopolitan, such as dogs, horses, cattle, chicken, wheat, yeast, maize, and rice. We established cooperative hunting groups with dogs that allowed us to obtain prey that were previously inaccessible" [10]. Research in agroecology reveals how agroecological approaches produce robust crop yields, little or no environmental damage, and significant levels of ecological regeneration when farmers collaborate with the natural functions of soil, water, native plants, native insects, and other aspects of the natural world (for numerous examples, see [14-17]). Our rapidly increasing scientific evidence of collaboration's role in the natural world is notable for anyone interested in the flourishing of life on Earth.

Rich discussion is simultaneously occurring regarding how to define a regenerative approach to how humans conduct their lives on Earth, and often nature's functions are being designated as models for human innovation. The term "regeneration" describes the self-renewing cycle of living systems and species on Earth and can apply to human well-being and socio-cultural flourishing as well as to the functions of the natural world. Camrass notes that regenerative approaches "move beyond harm mitigation to explore alternative approaches to the creation and maintenance of socially and ecologically resilient communities" [1]. One arena in which numerous discussions of regeneration are developing focuses on how the built environment may become more a regenerative than a degenerative presence. "Within regenerative development and design, built projects, stakeholder processes and inhabitation are therefore collectively focused on enhancing life in all its manifestations-human, other species, ecological systems-through an enduring responsibility of stewardship ... " [18]. In a regenerative approach, "an understanding of "eco-systematic order' should underpin the design of human environments" such that human actions are deeply compatible with how nature's systems function [18]. "Regenerative Development uses the term 'partners' to describe the members of an ecological system in the sense of partners in the business of creating the conditions that support healthy life in the place they co-inhabit. In this biocentric perspective, value is defined in terms of benefits 
to life. Adding value to an ecological system means increasing its systemic capability to generate, sustain and evolve increasingly higher orders of vitality and viability for the life of a particular place" [19]. Thus, increasingly, it appears that nature's regenerative models may become models for the human built environment and ways of living.

In recent centuries when the Industrial Revolution advanced human power and allowed us to step potently out of collaboration and into large-scale domination of nature, which has disrupted nature's regenerative cycles, we have created great harm to other species and Earth's systems; simultaneously we have eased the circumstances of human life. However, while we have succeeded in increasing physical comforts, lifestyle choices, medical care, and lifespans, we also have harmed our health through our emission of pollutants into our air, water, soil, and food and through our instigation of climate change. It is likely no coincidence that the age of industrial progress, which also has been an age of environmental domination and devastation (c. 1850-present), has additionally been an age of anxiety and depression, for we may be naturally attuned to care for our life support system rather than damage it, and we experience distress when our environment is damaged [11,20-24]. Regenerative action, thus, aims as much at renewing human well-being as it aims at renewing the natural world.

Notably, the "new stories" offered by environmental advocates as pathways out of our patterns of abuse of the planet include human-nature collaboration among their core assumptions. Advocates of adopting a new, collaborative story about humanity's relationship with Earth include Thomas Berry [25], Mary Evelyn Tucker [26], and Brian Swimme [27] (using the terms Great Work and Journey of the Universe); Wangari Maathai (Replenishing the Earth) [28]; Joanna Macy [29], Chris Johnstone [29], and David Korten [30] (The Great Turning); the Transition Movement (Rob Hopkins and activists around the world) [31]; Vandana Shiva (Earth Democracy) [32]; Marc Bekoff (Rewilding our Hearts) [33]; Gregory Cajete (Native Science) [34]; and Stephan Harding (Holistic Science) [11], among many others. Humanity appears to be engaged in recognizing and reclaiming the story of collaboration as central to the flourishing of life on Earth, seeing ourselves once again as participants rather than dominators [4,11,34]. As Figueres and Rivett-Carnac state regarding how to solve the climate crisis, "We are entering the next phase of human evolution .... [and] we need to prioritize collaboration .... We can ignite regenerative human cultures that seek to ensure that humanity becomes a life-sustaining influence on all ecosystems and on the planet as a whole" [35].

Just as science reveals collaboration to be an important feature of how the natural world functions, and as environmental advocates recommend that we adopt "new stories" about the collaboration that should characterize the human-Earth relationship, human value systems past and present have often promoted collaboration. Examples range from the Golden Rule ("treat others as you wish to be treated"), which appears in nearly all world religions, implying that people can collaboratively ensure good treatment of one another, to world religions' scriptures that emphasize care for Creation, which the Creator offers to humanity as a life-support system (see the Harvard University Press series Religions of the World and Ecology for in-depth discussion), to the ways indigenous spirituality worldwide advocates for harmonious collaboration between people and the natural world and the way we define democracy as a system of collaborative compromises with shared responsibilities and privileges. Documents of global relevance such as The Earth Charter and the Sustainable Development Goals contain a foundational assumption of collaboration: namely, that humans must work together, and cooperate with Earth's needs and limits, in order to ensure the flourishing continuation of life on Earth. It appears reasonable to assert that from the perspective of both our scientific knowledge base and human values systems, collaboration is a prominent feature of thriving on planet Earth, while a regenerative, continual renewal of life is a hallmark of how Earth's species and systems function when not interrupted by human actions.

During the 20th and 21st centuries, when humanity has had to face the damage caused by our efforts to dominate the natural world, we simultaneously have faced the damage 
caused by our efforts to dominate one another. Our ongoing endeavors to repair the damage caused by gender discrimination, slavery, and unjust systems that create poverty evince our advancing awareness that domination does not yield long-term success or peace. Perhaps we are ready to conclude that domination, whether of the natural world or other people, has been a failed experiment. Numerous cultural, political, and legal movements of the 20th and 21st centuries have been focused on how people collaboratively can promote and protect equality, rights, and the flourishing of all individuals and their communities. In the modern centuries we appear to be engaged in a continual extension of the human rights articulated by 17 th-century Enlightenment thinkers such as John Locke. These rights originally were intended primarily for white males yet gradually have been extended to include all humans, as well as animals, ecosystems, and plants, among those who possess natural rights. Examples of the extension of rights appear in rights movements of many kinds, from the spreading of democracy to endeavors to end child labor, abuse of animals and ecosystems, and discrimination based on sex, race, age, or physical status. The establishment of ecocide as a crime and the actions of countries such as Bolivia and New Zealand to encode formal legal rights for nature represent important legal approaches to halting domination.

What we must do now is to accept that life on Earth requires collaboration and currently is in need of regeneration. We then can re-enter the collaborative process deliberately and caringly, choosing our human activities within frameworks of regenerative collaboration. While my focus here is to discuss how regenerative collaboration can guide higher education to contribute substantively to solving our environmental crisis, the concept of regenerative collaboration is applicable as much to collaboration, justice, and healing within the human community as it is focused on collaboration, justice, and healing between humanity and the natural world.

Although regenerative collaboration can exist in a diversity of forms, and within a diversity of cultures, locations, and contexts, four principles are broadly applicable and can guide university education to prepare students to contribute to a new era of regeneration on Earth:

- All forms of life have value and a right to survive and flourish. This principle has bases in ethical frameworks such as the assertions of Albert Schweitzer in his essay "Reverence for Life" [36], Shiva's Principles of Earth Democracy [32], The Earth Charter, and The Deep Ecology Platform, among others, as well as world religions' foundational beliefs.

- Regenerative collaboration among humans, and among humans and all life forms, is the path forward if we value the flourishing of all forms of life and their right to survive. Vandana Shiva comparably states in her Principles of Earth Democracy, "Living cultures are life nourishing" [32], while Robin Wall Kimmerer formulates a similar idea via the recommendation that we learn to become "cultures of reciprocity" with nature [4] see also [34].

- Justice and flourishing for the Earth, all humans, and all animals, plants, and other life forms, is one and the same. As Nobel Laureate Wangari Maathai stated, "In degrading the environment, we degrade ourselves and all humankind ... In the process of helping the earth to heal, we help ourselves" (cf. [28,35]).

- Regenerative collaboration requires listening of many types: listening via scientific measurements of the natural world's health and human populations' mental and physical health; listening via indigenous and scientific approaches of tending and attending to ecosystems $[4,37,38]$, see also [11,39-41]; listening to plants [4,42]; listening to animals [33,43-45]; (and listening to and meeting human needs [31,32,46,47]. (While dominance approaches forbid listening [11], collaboration requires it as a continual practice. Listening is vital for overcoming domination because it recognizes that every life form has a set of needs or perspectives that others can perceive, and it reveals that every life form contributes to the larger life community. 
The concept of regenerative collaboration arises from indigenous values along with the scientific, ethical, and religious perspectives that have developed in post-indigenous cultures. This includes the values of indigenous people of color and also the indigenous values of all peoples, of every ethnic and racial origin, because every human being has an indigenous ancestry, however distant-though we have been more aware of the values of indigenous people of color in recent decades. Indigenous cultures worldwide appear to have viewed, and continue to view, the world as a regenerative collaboration. As the Lakota Luther Standing Bear wrote in 1933, "Kinship with all creatures of the earth, sky, and water was a real and active principle... The concept of life and its relations ... gave [the Lakota] reverence for all life; it made a place for all things in the scheme of existence with equal importance for all" [48], see also [49]. Potawatomi botanist Robin Wall Kimmerer discusses indigenous respect for the living world via her concept of "the grammar of animacy" [4]. Moreover, as Tewa Pueblo scholar Gregory Cajete states, American Indians traditionally understand "education" as a means of learning how to live "in a relational universe," or what this article terms an exchange of regeneratively collaborative behavior [34]. Thomas Berry, a scholar of indigenous spirituality and world religions, concluded that a crucial aim for the 21st century is to once again regard the world "as a communion of subjects" rather than "a collection of objects" [25]. Kyle Whyte offers a current perspective on traditional ecological knowledge as a collaborative concept and a knowledge base for ecological restoration [49]. Regenerative collaboration has robust roots in both scientific evidence and modern and pre-modern human values. As a focus in higher education, regenerative collaboration is new; yet, simultaneously, it is a recognition and compilation of age-old biological realities and human perspectives.

\section{Regenerative Collaboration in Practice in Higher Education}

Applying the regenerative collaboration framework to higher education assumes a transformative education model that challenges "prevailing myths and assumptions about ourselves and our place in the world" [8,50]. This is a re-evaluation and re-prioritization of education so that it aims, first and foremost, to value and protect the life community and its members of all species, and to promote their flourishing above any other goal. As Nicholas Maxwell has recommended, our aim must be "transforming universities ... so that humanity may learn how to make social progress toward a better, wiser, more civilized, enlightened world" [6], see also [12]. As Fazey et al. discuss, higher education has often experienced evolution, and it is now time for its next stage [8,24].

How a regenerative collaboration approach will function will be variable and must be assessed by individual higher education institutions (see J. Armon for a model of sustainability education that is comparable to regenerative collaboration yet more complex in its framework [51]). There is room for a diversity of approaches. However, applying regenerative collaboration as a framework for higher education aims to create two major outcomes:

1. The regenerative collaboration framework maintains all existing higher education disciplines in the humanities, social sciences, sciences, engineering, health sciences, business, law, et al. yet asks them to assess their disciplinary body of knowledge in light of the four regenerative collaboration principles listed above, to determine how their discipline may teach students via the framework of regenerative collaboration, and to assess how faculty research may incorporate a regenerative collaboration lens.

2. The regenerative collaboration framework includes in all students' degree programs the requirement to learn at least two or three practical regenerative skills.

\section{Regenerative Collaboration at the Level of Disciplines and Departments}

What might be the impact of the regenerative collaboration framework on individual academic disciplines and departments? Members of every academic discipline, and each department in a university, can begin by examining the discipline's core assumptions, content, and teaching aims. They then can define adjustments that would need to occur so 
that the discipline, department, and courses taught recognize regenerative collaboration as a reality and goal of life on Earth. When regenerative collaboration is embraced as the ultimate goal of a discipline, department, and courses, then it becomes desirable for the discipline, department, and courses to provide education that promotes conditions conducive to the flourishing and regeneration of all forms of life on Earth. Course content then shifts as needed to incorporate (and eventually be centered around) a regenerative collaboration lens. Of crucial importance is that the focus of courses becomes collaboration among humans and between humans and nature, not domination. Shifting courses toward this focus is a significant, and even a revolutionary, change, but, arguably it is essential if we are to move beyond our relatively unsuccessful experiments in sustainability and achieve regeneration of our planet's systems.

Some of what this article recommends is occurring in higher education, even at a significant scale. However, academic practitioners of these approaches can feel like lone operators if their departments and disciplines have not yet embraced regenerative thinking. Even fewer universities have done so, though notable examples of institutions with a bent that may qualify as "regenerative" include Schumacher College in the UK and Prescott College in Arizona. Osman et al. detail how Universiti Sains Malaysia is comprehensively incorporating sustainability in governance, operations, teaching, research, staff development, student skill-building, and community engagement through their University the Garden concept with a depth that may be moving toward regenerative collaboration [52]. Universiti Sains Malaysia's approach includes a required sustainability knowledge and skills course for first-year students and a much-needed acknowledgement of justice issues and the plight of the world's "bottom billion" [52].

There is ample room for scholars in any discipline to envision and specifically recommend how regenerative collaboration can guide their discipline's teaching and scholarship. Here, I offer examples relevant to the humanities, social sciences, and sciences.

A humanities or social science course can easily consider past and/or present cultures' values and practices via the lens of regenerative collaboration by exploring whether a set of values and practices facilitate(d) the flourishing of all life. Courses in disciplines such as history, philosophy, ethics, anthropology, psychology, political science, and sociology can emphasize the query, "Which values and practices promote flourishing and regeneration for all beings?" (Lander offers a model of Four Pillars of Wisdom relevant to education for sustainability that may help faculty assess their discipline and their course design; [53], see also $[54,55])$. Students might, for example, study world religions' scriptural statements on the human-nature relationship, or political theory and constitutional documents, through a regenerative collaboration lens. We need more focused discussions of topics such as John Locke's (and most of modern culture's) definition of land as human property, as compared to indigenous biologist Robin Wall Kimmerer's assessment of land and nature's systems as belonging to themselves while serving as homes and providing ecosystem services and physical and spiritual partnership with humanity [4,56]. (It is humanities and social sciences courses that are most likely to successfully delve into what David Orr has called the "disorder of [the human] mind" that has led to our disordered treatment of the natural world [57]. Assisting students to see, for example, that Francis Bacon's seminal scientific writings advocated for scientific progress, which has massively benefited human life [58], yet also for objectification of the natural world as a corpse on the dissection table [59], allows them to understand core modern assumptions that have steered us toward the objectification and domination of nature rather than reverence for and collaboration with nature $[11,60]$. These types of study also allow students to see that human practices evolve out of human values. Therefore, if we desire to live in regenerative collaboration with the natural world, we are free to choose to adjust our values and practices accordingly. From this perspective, regenerative collaboration appears within our reach.

Cross-disciplinary courses are well-suited to regenerative collaboration. A student in my justice-oriented regenerative agriculture course (a course that is offered both through a Peace and Justice Program and as an environmental studies course), recently wrote a paper 
on how her peers at our university could become involved in addressing food injustice in systemically regenerative ways, not simply via handouts to those experiencing hunger. She is now bringing the array of strategies she designed to two organizations on campus that will consider implementing them so students become aware of food access issues and learn to implement structural solutions [61].

Case studies abound on how higher education is weaving sustainability more substantively into its disciplines, going beyond 20th century approaches that often were more superficial in content and were isolated within lone departments such as environmental science. Albiz, for example, offers a case study of incorporating sustainability deeply into the five largest industrial engineering and management programs in Sweden by normalizing it as an area of required competency for graduates [62]. Iyer-Raniga and Dalton discuss integrating sustainability education into coursework in several disciplines related to the built environment in Indonesia [63]. This type of implementation of a sustainability focus can easily be transformed into the greater depth of regenerative values and actions. What has been termed comprehensive sustainability education, a deep approach akin to regenerative collaboration, is being developed across the higher-ed course curriculum in disciplines as varied as literature, sustainable development, religion, accounting, education, and agriculture [64].

Stephan Harding's Holistic Science, which emphasizes human participation in nature rather than mastery over nature, exemplifies how a regenerative collaboration approach might function in a science course [11]. Harding's invitations to personally encounter the natural world are models of one way that faculty can invite students into learning through the lens of regenerative collaboration. In the engineering context, an engineering student of mine in her final year of her degree recently wrote a paper proposing that all courses in the Villanova School of Engineering Environmental and Civil Engineering majors emphasize both environmental justice and social justice, and some faculty have shown interest in her proposal [65]. What is needed at this time is for frameworks such as regenerative collaboration to inspire a rapid scaling-up of the number of departments, institutions, and entire disciplines that commit to substantive involvement not only in sustainability but also in the work of regenerating planetary and human health.

\section{Practical Regenerative Skills in Higher Education}

The rationale for incorporating the development of practical regenerative skills into undergraduate and graduate learning is that it will enable students to graduate with abilities to substantively contribute to the regeneration of our damaged planet needs, rather than only with awareness (or lack of awareness) about the problems we face globally. Learning practical skills also reminds students that human beings are creative problemsolvers who can accomplish remarkable things when we so choose and empowers them to enact the planetary regeneration many of them indicate that they desire [66-68]. The criteria for a skill to qualify as a "practical regenerative skill" are that it benefits the regenerative thriving of the life community while creating minimal or no harm and that it emphasizes mutually beneficial collaboration among people and between people, plants, animals, and ecosystems.

I have found in my own teaching that students are hungry to learn practical skills. When I had an opportunity to build a cob oven with students, they asked for additional such experiences. When students in my regenerative agriculture course experience fieldwork on organic farms, they often seek additional active learning that builds their practical skills $[3,67]$. Students repeatedly have told me they would welcome opportunities within their higher education degree programs to learn to grow food, install solar panels, build stormwater treatment rain gardens, facilitate community dialogue related to sustainability/regenerative action or environmental (in)justice, or prepare nutritious food. Many academic disciplines, such as nursing, forestry, education, environmental science, and some fields in engineering, already require students to acquire practical skills as part of their degree program. The value of experiential learning has been studied [69-71], and it 
is being identified as important in transformative sustainability education [6,8]. Requiring the development of regenerative skills across disciplines and majors also might carry the benefit of helping students and their families feel less wary of pursuing degrees in the "impractical" fields of study in the humanities and social sciences, because whether students graduate with an English, philosophy, sociology, history, biology, engineering, or nursing degree, they all can develop two or three practical skills that are applicable both to regenerative action and to finding employment.

Including practical regenerative skills within the education experienced by all students in higher education can occur at the level of departmental instruction, requirements for majors, and requirements for graduation. Practical regenerative skills may be developed in academic courses with existing or new fieldwork and lab components, as well as during internships, campus volunteer programs, and summer experiences. This skill-building also can occur within campus work-study employment opportunities in which students learn to build rain gardens on campus; install native plantings to support native plant, insect, and bird species; install solar panels, green roofs, or energy-conservation measures; or cultivate food in a campus garden. Because many campuses already are engaged in these endeavors, incorporating student learning into them is not a far stretch (see [72] for case studies of substantive campus sustainability/regeneration measures). Botero et al. discuss how Stuttgart's University of Applied Sciences has extended its campus experiments in climate neutrality to benefit the broader community, utilizing real-world laboratories for research and student learning, and exemplifying how campus engagement in sustainability/regeneration can have benefits beyond academia, both in terms of sustainability/regeneration awareness and practical implementation [73]. Hansen discusses Macalester College's Living Laboratory, whose multi-disciplinary classes, internships, and student research exemplify what can be scaled up in a regenerative collaboration approach. Hansen notes that Portland State, Penn State, and Princeton Universities also are utilizing or creating similar Living Laboratories for student learning and skill-building [74].

Practical regenerative skills that become part of higher education degrees may range from permaculture, plant and tree care, wild lands restoration, "green" construction methods, wildlife rehabilitation, or natural stormwater management, to the community development skills taught within the Transition Towns movement and various approaches to non-violent and inclusive conflict resolution (such as non-violent communication and social permaculture). Regenerative agriculture should be strongly emphasized, for it alone appears to have the potential to reverse climate change harmlessly through carbon sequestration while regenerating ecosystems and feeding humanity [75]. Practical regenerative skills also include the ability to engage in quiet contemplation in nature to explore what it means to be present to the life community in an observational or intuitive capacity (cf. [11,40,41]); food production in a neighborhood facing food injustice; strategies for cradle-to-cradle handling of materials and waste; and the design of new materials that can be regeneratively produced and recycled, such as products made of mycelium. Additional skills can be added to this preliminary list and will vary somewhat by discipline, campus needs, and campus location. A next step is for scholars and administrators to create a public, international, and evolving list of regenerative skills that can be learned in the higher education context (see the chapters in Stibbe for additions to the list of skills noted here [76]).

When assessing regenerative collaboration and skill-building in higher education, it may be helpful to distinguish initially between emergency regenerative collaboration measures and deep regenerative collaboration measures. In an example of emergency regenerative collaboration measures, the city of Philadelphia has committed to dim downtown high-rise buildings' lights to alleviate migrating birds' night-time visual disruptions. Similarly, an academic department might decide to immediately adapt at least one or two courses to focus on how regenerative collaboration applies to its discipline. Deep regenerative collaboration measures include re-designing a university's entire course offerings to focus on regenerative collaboration and revising its campus systems for substantially 
improved wildlife habitat and human food access, renewable energy use or production, and local processing of waste.

\section{Conclusions}

Imbuing higher education disciplines, courses, and institutions with a regenerative collaboration emphasis will offer students continual opportunities to encounter the depth and breadth of its applicability, thus facilitating the ethical and cultural re-envisioning, and the development and application of practical regenerative skills that our environmental crisis demands. This is a major step toward achieving what Thomas Berry described in 1999 as the Great Work of the 21st century, to transition humanity from being a devastating presence to a "mutually beneficial" presence existing in co-creative partnership with the natural world [25].

An important area to track longitudinally will be the impact on students who experience an education oriented toward regenerative collaboration. My observation over time has been that many students feel frightened or overwhelmed by our global environmental problems and helpless to create change. When coursework provides students opportunities to learn about solutions and to gain skills in implementing solutions, they indicate that they feel the optimism, confidence, or determination that humanity appears to require now if we are to resolve our global environmental crisis. It will be helpful to track how students' satisfaction with their degrees, employability, mental health, and contributions to environmental regeneration evolve when they experience an education that emphasizes regenerative collaboration.

The work of teaching students enrolled in higher education how to exist in partnership with the natural world that is our life support system, rather than in dominance over other life forms, already has begun in substantive ways around the world. It needs now to be more clearly communicated via accessible frameworks, then implemented to scale in institutions of higher education. Regenerative collaboration can provide a framework for preparing students to enact the repair Earth needs.

Funding: This research received no external funding.

Conflicts of Interest: The author declares no conflict of interest.

\section{References}

1. Camrass, K. Regenerative Futures. Foresight 2020, 22, 401-415. [CrossRef]

2. Eaton, M.; Davies, K.; Williams, S.; MacGregor, J. Why Sustainability Education Needs Pedagogies of Reflection and Contemplation. In Contemplative Approaches to Sustainability in Higher Education; Eaton, M., Hughes, H., MacGregor, J., Eds.; Routledge: New York, NY, USA, 2017; p. 3.

3. Armon, C. An education that heals: Purposes and practices guided by the Great Work. In Prioritizing Sustainability Education: A Comprehensive Approach; Armon, J., Scoffham, S., Armon, C., Eds.; Routledge: London, UK, 2020; pp. 57, 59.

4. Kimmerer, R.W. Braiding Sweetgrass: Indigenous Wisdom, Scientific Knowledge, and the Teachings of Plants; Milkweed Editions: Minneapolis, MN, USA, 2013; pp. 6, 20, 25-28, 31, 55-58, 115, 116, 165; 175, 177-178, 183, 189 ff., 336.

5. Orr, D.F. Teaching Sustainability: Perspectives from the Humanities and Social Sciences; Petersen-Boring, W., Forbes, W., Eds.; Stephen F. Austin University Press: Nacogdoches, TX, USA, 2014; p. XI.

6. Maxwell, N. How Universities Have Betrayed Reason and Humanity—And What's to Be Done About It. Front. Sustain. 2021, 2, 18.

7. Maxwell, N. How Universities Can Help Create a Wiser World; Imprint Academic: Exeter, UK, 2014; pp. 29, 69, et passim.

8. Fazey, J.; Hughes, C.; Schapke, N.; Leicester, G.; Eyre, L.; Goldstein, B.; Hodgson, A.; Mason-Jones, A.; Moser, S.; Sharpe, B.; et al. Renewing Universities in Our Climate Emergency: Stewarding System Change and Transformation. Front. Sustain. 2021, 2, 677904. [CrossRef]

9. Saffo, M.B. Mutualistic Symbioses; eLS. John Wiley \& Sons, Ltd.: Chichester, UK, 2014.

10. Guimarães, P.R., Jr; Pires, M.M.; Marquitti, F.M.D.; Raimundo, R.L.G. Ecology of Mutualisms; eLS. John Wiley \& Sons, Ltd.: Chichester, UK, 2016.

11. Harding, S. Animate Earth: Science, Intuition, and Gaia; Green Books: Cambridge, UK, 2013; pp. 22, 25, 28-33, 34, 35, 39, 43, 163, 164, 192, 230, 253, 271, 274.

12. Lopez-Lopez, M.C.; Martínez-Rodríguez, F.M.; Fernández-Herrería, A. The University at the Crossroads of Eco-Social Challenges: Pedagogy of Care and the Community of Life for a Transformative Learning. Front. Sustain. 2021, 2, 14. 
13. Simard, S. Finding the Mother Tree; Knopf: New York, NY, USA, 2021; pp. 121-122, 144-147.

14. Brescia, S. (Ed.) Fertile Ground: Scaling Agroecology from the Ground Up; Food First Books: Oakland, CA, USA, 2017.

15. Altieri, M.A. How bugs showed me the way to Agroecology. Agroecol. Sustain. Food Syst. 2020, 44, 1255-1259. [CrossRef]

16. Altieri, M.A.; Nicholls, C. Agroecology and the emergence of a post COVID-19 agriculture. Agric. Hum. Values 2020, 37, 525-526. [CrossRef] [PubMed]

17. Bover-Felices, K.; Suarez-Hernandez, J. Contribution of the agroecology approach in the functioning and structure of integrated agroecosystems. Pastos y Forrajes 2020, 43, 96-104.

18. Robinson, J.; Cole, R.J. Theoretical underpinnings of regenerative sustainability. Build. Res. Inf. 2015, 43, 133-143. [CrossRef]

19. Mang, P.; Reed, B. The nature of positive. Build. Res. Inf. 2015, 43, 7-10. [CrossRef]

20. Fisher, A. Radical Ecopsychology: Psychology in the Service of Life; SUNY Press: Albany, NY, USA, 2002; Chapters 1 and 6.

21. Leetch, A.; Hauk, M. A Decade of Earth in the Mix: A Bibliometric Analysis of Emergent Scholarly Research on Sustainability Education and Ecopsychology in Higher Education. In Handbook of Theory and Practice of Sustainable Development in Higher Education; Filho, W.L., Mifsud, M., Shiel, C., Pretorius, R., Eds.; Springer: Cham, Switzerland, 2017; Volume 3, pp. $291-306$.

22. Northcott, M.S. Place, Ecology, and the Sacred; Bloomsbury: London, UK, 2015; p. 3.

23. Palamos, K. Nature, Human Ecopsychological Consciousness and the Evolution of Paradigm Change in the Face of Current Ecological Crisis. Int. J. Transpers. Stud. 2016, 35, 88-92. [CrossRef]

24. Moser, S.; Fazey, J. If It Is Life We Want: A Prayer for the University. Front. Sustain. 2021, 2, 30.

25. Berry, T. The Great Work. Our Way into the Future; Bell Tower: New York, NY, USA, 1999; pp. X, 3, 7, 16, 55.

26. Tucker, M.E. Thomas Berry and the New Story: An Introduction to the Work of Thomas Berry. In The Intellectual Journey of Thomas Berry: Imagining the Earth Community; Eaton, H., Ed.; Lexington Books: Lexington, NY, USA, 2014.

27. Tucker, M.E.; Swimme, B. Journey of the Universe; Yale University Press: New Haven, CT, USA, 2011.

28. Maathai, W. Replenishing the Earth; Doubleday: New York, NY, USA, 2010; pp. 17, 25.

29. Macy, J.; Johnstone, C. Active Hope; New World Library: Novato, CA, USA, 2012.

30. Korten, D.C. The Great Turning. From Empire to Earth Community; Berrett-Koehler Publishers: San Francisco, CA, USA, 2006.

31. Hopkins, R. The Transition Companion; Chelsea Green: White River Junction, VT, USA, 2011.

32. Shiva, V. Earth Democracy; South End Press: Brooklyn, NY, USA, 2005; pp. 9-11.

33. Bekoff, M. Rewilding Our Hearts: Building Pathways of Compassion and Co-Existence; New World Library: Novato, CA, USA, 2014; pp. 2,6,7.

34. Cajete, G. Native Science; Clear Light Publishers: Santa Fe, NM, USA, 2000; pp. 65, 262, et passim.

35. Figueres, C.; Rivett-Carnac, T. The Future We Choose: Surviving the Climate Crisis; Knopf: New York, NY, USA, 2020; pp. 32, 33, 66, 76.

36. Schweitzer, A. Reverence for Life; Reginald, H.F., Translator; Irvington Publishers: New York, NY, USA, 1969.

37. Shorty, L. A Navajo's Meditations on Food and Culture. In A People's Ecology; Cajete, G., Ed.; Clear Light: Santa Fe, NM, USA, 1999; pp. 136-141.

38. Salmon, E. Eating the Landscape. American Indian Stories of Food, Identity, and Resilience; University of Arizona Press: Tucson, AZ, USA, 2012; pp. 43, 44, 53, 54, 88, 118.

39. Barrett, M.J.; Harmin, M.; Maracle, B.; Patterson, M.; Thomson, F.M.; Flowers, M.; Bors, K. Shifting relations with the more-thanhuman: Six threshold concepts for transformative sustainability learning. Environ. Educ. Res. 2017, 23, 131-143. [CrossRef]

40. Jackson, W. Becoming Native to this Place; Counterpoint: Berkeley, CA, USA, 1996; pp. 25, 83, 112.

41. Jackson, W. Nature as Measure; Counterpoint: Berkeley, CA, USA, 2011; p. 56.

42. Hall, M. Plants as Persons: A Philosophical Botany; SUNY Press: Albany, NY, USA, 2011; Chapter 7.

43. Bekoff, M.; Jessica, P. Wild Justice: The Moral Lives of Animals; University of Chicago Press: Chicago, IL, USA, 2009.

44. Bekoff, M. Afterword: The Emotional and Moral Lives of Animals: What Darwin Would Have Said. In After Darwin: Animals, Emotions, and the Mind; Richardson, A., Ed.; Brill: Amsterdam, The Netherlands, 2013.

45. Barrett, M.J.; Hinz, H.; Wijngaarden, V.; Lovrod, M. "Speaking” with Other Animals through Intuitive Interspecies Communication: Towards Cognitive and Interspecies Justice. In A Research Agenda for Animal Geographies; Hovorka, A., McCubbin, S., van Patter, L., Eds.; Edward Elgar Publishing Ltd.: Cheltenham, UK, 2021; Chapter 10.

46. Caraway, R.T. Deep Green and Social. Permaculture, Spirituality, and Society in Cuba. Nova Relig. J. Altern. Emergent Relig. 2020, 24, 5-31. [CrossRef]

47. Penniman, L. Farming While Black; Chelsea Green: White River Junction, VT, USA, 2018; Introduction, Chapters 14, 16.

48. Standing Bear, L. Land of the Spotted Eagle; University of Nebraska Press: Lincoln, CA, USA, 2006; p. 133.

49. Whyte, K.P. On the role of traditional ecological knowledge as a collaborative concept: A philosophical study. Ecol. Process. 2013, 2, 7. [CrossRef]

50. Selby, D. Thoughts from a Darkened Corner: Transformative Learning for the Gathering Storm. In Sustainability Frontiers: Critical and Transformative Voices from the Borderlands of Sustainability Education; Selby, D., Kagawa, F., Eds.; Barbara Budrich Publishers: Berlin/Heidelberg, Germany, 2015; p. 32.

51. Armon, J. Introduction. In Prioritizing Sustainability Education: A Comprehensive Approach; Armon, J., Scoffham, S., Armon, C., Eds.; Routledge: London, UK, 2020. 
52. Osman, O.; Ibrahim, K.; Koshy, K.; Akib, N.A.M.; Shabudin, A.F.A. The Sustainability Journey of USM: Solution Oriented Campus Ecosphere for Vitalising Higher Education Action on GAP. In Handbook of Theory and Practice of Sustainable Development in Higher Education; Filho, W.L., Mifsud, M., Shiel, C., Pretorius, R., Eds.; Springer: Cham, Switzerland, 2017; Volume 3, pp. 377-390.

53. Lander, L. Education for Sustainability: A Wisdom Model. In Handbook of Theory and Practice of Sustainable Development in Higher Education; Filho, W.L., Mifsud, M., Shiel, C., Pretorius, R., Eds.; Springer: Cham, Switzerland, 2017; Volume 3, pp. 47-58.

54. Petersen-Boring, W. Sustainability and the Western Civilization Curriculum: Reflections on Cross-pollinating the Humanities and Environmental History. Environ. Hist. 2010, 15, 288-304. [CrossRef]

55. Petersen-Boring, W.; Forbes, W. (Eds.) Teaching Sustainability: Perspectives from the Humanities and Social Sciences; Stephen F. Austin University Press: Nacogdoches, TX, USA, 2014.

56. Locke, J. Two Treatises of Government; Peter, L., Ed.; Cambridge University Press: Cambridge, CA, USA, 1988; pp. 285-287, $289,291$.

57. Orr, D.F. Ecological Literacy; Stone, M.K.S., Barlow, Z., Eds.; Sierra Club Books: San Francisco, CA, USA, 2005; p. X.

58. Bacon, F. The Great Instauration and New Atlantis; Weinberger, J., Ed.; AHM Publishing Corporation: Arlington Heights, IL, USA, 1980; p. 16.

59. Bacon, F. Novum Organum. In The Works of Francis Bacon; Spedding, J., Ellis, R., Heath, D., Eds.; Garrett Press: New York, NY, USA, 1968; Volume IV, pp. 110, 114, 246-248.

60. Muller, E. Regenerative Development in Higher Education: Cost Rica's Perspective. In Higher Education in the Era of the Fourth Industrial Revolution; Gleason, N.W., Ed.; Palgrave MacMillan: Singapore, 2018; p. 122.

61. Nguyen, C. From the Ground Up: A Villanovan's Guide to Being a Food Justice Advocate, A Paper Submitted to the Course Growing into Justice through Agriculture; Villanova University: Villanova, PA, USA, 2020.

62. Albiz, N. Identifying Relevant Versus Received Sustainability Education at Industrial Engineering and Management Programs. In Handbook of Theory and Practice of Sustainable Development in Higher Education; Filho, W.L., Mifsud, M., Shiel, C., Pretorius, R., Eds.; Springer: Cham, Switzerland, 2017; Volume 3, pp. 115-131.

63. Iyer-Raniga, U.; Dalton, T. A Holistic View for Integrating Sustainability Education for the Built Environment Professions in Indonesia. In Handbook of Theory and Practice of Sustainable Development in Higher Education; Filho, W.L., Mifsud, M., Shiel, C., Pretorius, R., Eds.; Springer: Cham, Switzerland, 2017; Volume 3, pp. 355-376.

64. Armon, J.; Scoffham, S.; Armon, C. (Eds.) Prioritizing Sustainability Education: A Comprehensive Approach; Routledge: London, UK, 2020.

65. Merrill, S. Reimagining the Civil and Environmental Engineering Curriculum, A Paper Submitted to the Course, Growing into Justice through Agriculture; Villanova University: Villanova, PA, USA, 2020.

66. Artis, Z.; Cohen, A.M.; Jaguzy, I.; Kieras, K. This is Zero Hour: Students Confront Educators. In Prioritizing Sustainability Education: A Comprehensive Approach; Armon, J., Scoffham, S., Armon, C., Eds.; Routledge: London, UK, 2020; pp. 27-35.

67. Armon, J.; Armon, C. Cultivating Intimacy with the Natural World: College Students' Care, Connection, and Regeneration in an Agriculture-focused Humanities Course. J. Sustain. Educ. 2015, 9.

68. Armon, C.; Armon, J. Toward Enchantment: Cultivating Nature Connection and Ecological Regeneration through Experiential Learning in Sustainable Agriculture. In Re-Enchanting the Academy; Voss, A., Wilson, S., Eds.; Rubedo Press: Seattle, WA, USA, 2017; pp. 281-303.

69. Backman, M.; Pitt, H.; Marsden, T.; Mehmood, A.; Mathijs, E. Experiential approaches to sustainability education: Towards learning landscapes. Int. J. Sustain. High. Educ. 2019, 20, 139-156. [CrossRef]

70. Kolb, D.A. Experiential Learning: Experience as the Source of Learning and Development; Pearson Education: Upper Saddle River, NJ, USA, 2014.

71. Roberts, J.W. Beyond Learning by Doing: Theoretical Currents in Experiential Education; Routledge: New York, NY, USA, 2012.

72. Filho, W.L.; Mifsud, M.; Shiel, C.; Pretorius, R. (Eds.) Handbook of Theory and Practice of Sustainable Development in Higher Education; Springer: Cham, Switzerland, 2017; Volume 3.

73. Botero, L.; Bossert, M.; Eicker, U.; Cremers, J.; Palla, N.; Schoch, C. A Real-World Lab Approach to the Carbon Neutral Campus Transition: A Case Study. In Handbook of Theory and Practice of Sustainable Development in Higher Education; Filho, W.L., Mifsud, M., Shiel, C., Pretorius, R., Eds.; Springer: Cham, Switzerland, 2017; Volume 3, pp. 73-88.

74. Hansen, S.S. The Campus as a Living Laboratory: Macalester College Case Study. In Handbook of Theory and Practice of Sustainable Development in Higher Education; Filho, W.L., Mifsud, M., Shiel, C., Pretorius, R., Eds.; Springer: Cham, Switzerland, 2017; Volume 3, pp. 223-239.

75. Moyer, J.; Smith, A.; Rui, Y.; Hayden, J. Regenerative Agriculture and the Soil Carbon Solution; The Rodale Institute: Kutztown, PA, USA, 2020.

76. Stibbe, A. (Ed.) The Handbook of Sustainability Literacy: Skills for a Changing World; Green Books: Totnes, UK, 2012. 